\title{
UPAYA MENINGKATKAN KOMPETENSI PEDAGOGIK GURU KELAS IV SD NEGERI 9 DAUH PURI MELALUI PENERAPANSUPERVISI AKADEMIK TAHUN PELAJARAN 2016/2017
}

\author{
Ni Made Kasniari \\ SD Negeri 9 Dauh Puri
}

\begin{abstract}
ABSTRAK
Penelitian ini bertujuan untuk meningkatkan Kompetensi Pedagogik Guru Kelas IV SD Negeri 9 Dauh Puri dan kemampuan guru menyusun RPP dalam Proses Pembelajaran dengan penerapan Supervisi Akademik.Jenis penelitian ini adalah penelitian tindakan sekolahdan melibatkan 1 orang guru SD Negeri 9 DauhPuri tahun pelajaran 2016/2017.Data penelitian ini meliputi data kompetensi pedagogik yang dikumpulkan menggunakan lembar kerja intrumen penilaian pelaksanaan pembelajaran dan kemampuan menyusun rencana pelaksanaan pembelajaran menggunakan instrumen perencanaan kegiatan pembelajaran. Selanjutnya data yang terkumpul dalam penelitian ini dianalisis dengan menggunakan statistik deskriptif.Hasil penelitian menunjukan bahwa terjadi peningkatan Kompetensi Pedagogik dan Kemampuan Menyusun RPP. Ini terbukti dari hasil yang di peroleh pada siklus $1.70 \%$ untuk menyusun RPP dan 73,33\% untuk kompetensi pedagogik. Dari siklus I ke siklus II meningkat $100 \%$ untuk penyusunan RPP dan 100\% untuk kompetensi pedagogik. Kesimpulan yang diperoleh dari penelitian ini adalah supervisi akademik dapat meningkatkan kompetensi pedagogik guru dan menyusun rencana pelaksanaan pembelajaran.
\end{abstract}

Kata kunci: Kompetensi Pedagogik dan Supervisi Akademik.

\section{ABSTRACT}

This study aims to improve the Pedagogical Competence of Class IV Teachers of SD Negeri 9 Dauh Puri and the ability of teachers to prepare RPP in the Learning Process by applying Academic Supervision. This type of research is school action research and involves 1 teacher at the Dauh Puri 9 Elementary School in the academic year 2016/2017.The data of this study include pedagogic competency data collected using worksheets for assessment instruments for the implementation of learning and the ability to develop learning implementation plans using planning instruments for learning activities. Furthermore, the data collected in this study was analyzed using descriptive statistics. The results showed that there was an increase in Pedagogic Competence and Ability to Arrange RPP. This is evident from the results obtained in the $1.70 \%$ cycle for preparing lesson plans and $73.33 \%$ for pedagogical competencies. From cycle I to cycle II it increased $100 \%$ for the preparation of RPP and $100 \%$ for pedagogic competencies. The conclusion obtained from this study is that academic supervision can improve the pedagogical competence of the teacher and develop a plan for implementing learning.

Keywords: Pedagogic Competence and Academic Supervision.

\section{PENDAHULUAN}

Proses pembelajaran di kelas akan sangat efektif apabila guru melaksanakan dengan memahami peran, fungsi dan kegunaan mata pelajaran yang di ajarnya. Selain pemahaman akan hal - hal tersebut, keefektifan itu juga di tentukan oleh kemampuan guru untuk membuat model model pengajaran menjadi model pembelajaran sesuai yang diharapkan oleh Permen No 41 Tahun 2007 tentang Standar Proses.Kelemahan - kelemahan 
yang terjadi selama proses pembelajaran yang dilakukan selama ini yang menyebabkan rendahnya prestasi belajar siswa tentu tidak sepenuhnya disebabkan oleh faktor luar seperti kesibukan guru, keadaan rumah tangga, lingkungan dan lain - lain. Kelemahan - kelemahan yang ada tentu banyak pula dipengaruhi oleh faktor dari dalam guru itu sendiri seperrti kemauan menyiapkan bahan ajar yang lebih baik, termasuk kamauan guru untuk mengembangkan keterampila mengajar yang dapat menarik perhatian siswa dan merangsang siswa untuk belajar.Keterampilan yang mesti dikuasai guru dalam meaksanakan pembelajaran ada 7(tujuh) yaitu: 1) Keterampilan bertanya. 2) Keterampilanmemberi penguatan. 3) Keterampilan mengadakan variasi. 4) Keterampilan menjelaskan. 5) Keterampilan membuka dan menutup pelajaran. 6) Keterampilan membimbing diskusi. 7) Keterampilan mengelola kelas. Keterampilan - keterampilan ini berhubungan dengan persiapan dan pelaksanaan proses pembelajaran yang akan memberi dukungan terhadap cara berpikir siswa yang aktif dan imajinatif. Hal inilah yang menunjukkan profesional guru (I.G.A.K. Wardani dan Siti Julaeha, Model IDIK 4307:1-30)Dari semua uraian diatas dapat diketahui hal - hal yang perlu dalam upaya meningkatkan kompetensi pedagogik guru seperti penugasan metode - metode ajar, penguasaan model - model pembelajaran, penguasaan teori - teori belajar, penguasaan teknik - teknik tertentu serta menyusun rencana pelaksanaan pembelajaran. Apabila betul betul guru menguasai dan mengerti tentang hal - hal tersebut dapat diyakini bahwa prestasi belajar peserta didik dapat di tingkatkan.Melihat kesenjangan antara harapan - harapan yang telah disampaikan dengan kenyataan di lapangan sangat jauh berbeda, dalam upaya memperbaiki mutu pendidikan sangat perlu kiranya dilakukan perbaikan cara pembelajaran. Salah satunya adalah Kompetensi Pedagogik Guru dan Menyusun Rancana Pelaksanaan Pembelajaran (RPP) dengan Menggunakan Penerapan Supervisi Akademik, oleh karenanya penelitian ini sangat penting untuk dilaksanakan.

Adapun tujuan dari penelitian ini adalah sebagai berikut: 1) Untuk menganalisis kontribusi supervisi akademik dalam meningkatkan Kompetensi Pedagogik guru Kelas IV SD Negeri9 DauhPuri. 2) Untuk menganalisis supervisiAkademikdalammeningkatkanke mampuan guru Kelas IV SD Negeri9 DauhPuridalam menyusun Rencana Pelaksanaan Pembelajaran (RPP).

\section{METODE PENELITIAN}

Penelitian ini merupakan Penelitian Tindakan Sekolah yang secara umum bertujuan memperbaiki Proses Pembelajaran di kelas tempat berlangsungnya penelitian tindakan yang dilakukan dalam penelitian ini adalah Penerapan supervisi akademik dalam meningkatkan kompetensi pedagogik guru.Subjek penelitian ini adalah guruKelasIVSD Negeri9 DauhPuriTahun Pelajaran 2016/2017 sebanyak 1 orang. Objek penelitian ini adalah Meningkatkan Kompetensi Pedagogik GuruKelas IVSD Negeri9 DauhPuridalam Pembelajaran dengan Penerapan Supervisi Akademik. 
Adapun prosedur penelitian dapat diuraikan dalam bagan berikut ini
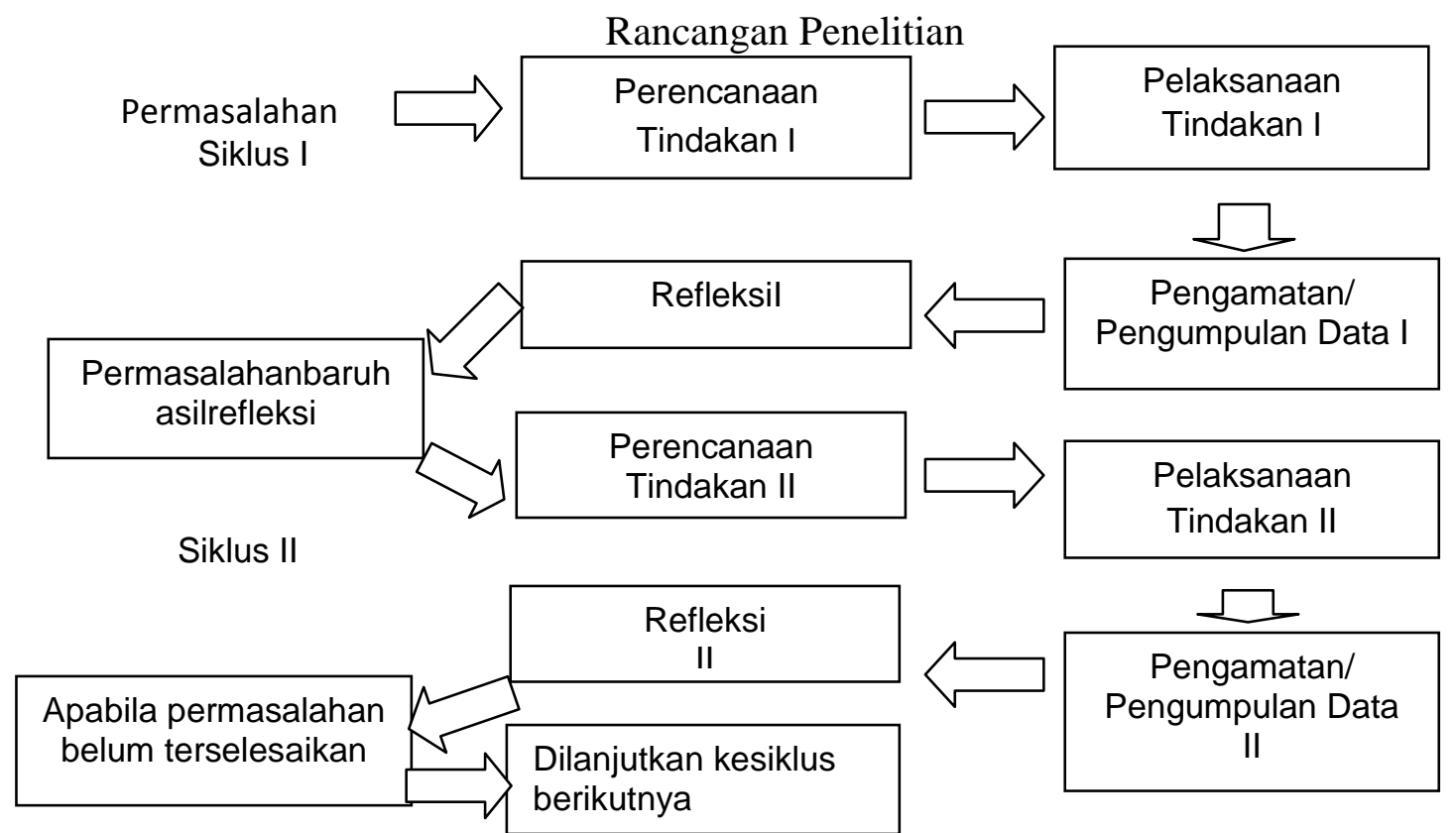

Diadopsi dari Suharsimi Arikunto, Suhardjono, Supardi (2006)

\section{Siklus I}

\section{Perencanaa Tindakan}

Untuk memperlancar jalannya penelitian sehingga memperoleh hasil yang optimal maka perlu disiapkan hal - hal sebagai berikut:

a. Mensosialisasikan supervisi akademik pada guru

b. Mengumpulkan RPP masing - masing guru

c. Menentukan jadwal supervisi kelas

d. Menyiapkan instrumen penelitian seperti RPP dan instrumen perencanaan kegiatan atau pembelajaran

\section{Pelaksanaan Tindakan}

Secara umum aspek yang diamati pada pelaksanaan tindakan pada siklus I dapat diuraikan sebagai berikut:

Kegiatan Pendahuluan

A persepsi dan Motivasi

1 Memberi salam pada peserta didik

2 Mengecek kehadiran siswa
3 Mengaitkan materi pembelajaran sekarang dengan pengalaman peserta didik atau pembelajaran sebelumnya.

4 Mengajukan pertanyaan menantang. Menyampaikan manfaat materi pembelajaran.

5 Mendemonstrasikan sesuatu yang terkait dengan materi pembelajaran.

Penyampaian Kompetensi dan Rencana Kegiatan

1. Menyampaikan kemampuan yang akan dicapai peserta didik.

2. Menyampaikan rencana kegiatan misalnya, individual, kerja kelompok, dan melakukan observasi.

a. KegiatanInti

Penguasaan Materi Pelajaran

1. Kemampuan menyesuiakan materi dengan tujuan pembelajaran.

2. Kemampuan mengkaitkan materi dengan pengetahuan lain yang relevan, 
perkembangan Iptek, dan kehidupan nyata.

3. Menyajikan pembahasan materi pembelajaran dengan tepat.

4. Menyajikan materi secara sistematis (mudah kesulit, dari konkrit ke abstrak)

Penerapan Strategi Pembelajaran yang Mendidik

1. Melaksanakan pembelajaran sesuai dengan kompetensi yang akan dicapai.

2. Menfasilitasi kegiatan yang memuat komponen eksplorasi, elaborasi dan konfirmasi.

3. Melaksanakan pembelajaran secara runtut.

4. Menguasai kelas.

5. Melaksanakan pembelajaran yang bersifat kontekstual.

6. Melaksanakan pembelajaran yang memungkinkan tumbuhnya kebiasaan positif (nurturant effect).

7. Melaksanakan pembelajaran sesuai dengan alokasi waktu yang direncanakan.

Penerapan Pendekatan scientific

1. Memberikan pertanyaan mengapa dan bagaimana.

2. Memfasilitasi peserta didik untuk mengamati.

3. Memancing peserta didik untuk bertanya.

4. Memfasilitasi peserta didik untuk mencoba.

5. Memfasilitasi peserta didik untuk menganalisis.

6. Memberikan pertanyaan peserta didik untuk menalar (proses berfikir yang logis dan sistematis).

7. Menyajikan kegiatan peserta didik untuk berkomunikasi.
Pemanfaatan Sumber Belajar/ Media dalam Pembelajaran

1. Menunjukkan keterampilan dalam penggunaan sumber belajar pembelajaran.

2. Menunjukkan keterampilan dalam penggunaan media pembelajaran.

3. Menghasilkan pesan yang menarik.

4. Melibatkan peserta didik dalam pemanfaatan sumber belajar pembelajaran.

5. Melibatkan peserta didik dalam pemanfaatan media pembelajaran.

Pelibatan Peserta Didik dalam Pembelajaran

1 Menumbuhkan partisipasi aktif peserta didik melalui interaksi guru, peserta didik, sumber belajar.

2 Merespon positif partisipasi peserta didik.

3 Menunjukkan sikap terbuka terhadap respons peserta didik.

4 Menunjukkan hubungan antar pribadi yang kondusif.

5 Menumbuhkan keceriaan atau antuisme peserta didik dalambelajar.

Melaksanakan Penilaian Autentik

1. Menilai sikap dalam pembelajaran

2. Menilai pengetahuan dalam proses pembelajaran

3. Menilai pengetahuan dalam proses pembelajaran

Penggunaan Bahasa yang Benardan Tepat dalam Pembelajaran

1. Menggunakan bahasa lisan secara jelas dan lancar.

2. Menggunakan bahasa tulis yang baik dan benar.

b. Kegiatan Penutup 
Penutup pembelajaran

1. Melakukan refleksi atau membuat rangkuman dengan melibatkan peserta didik.

2. Memberikan tes lisan atau tulisan .

3. Mengumpulkan hasil kerja sebagai bahan portofolio.

4. Melaksanakan tindak lanjut dengan memberikan arahan kegiatan berikutnya dan tugas pengayaan.

\section{Observasi}

Selama pelaksanaan tindakan pada siklus I diadakan observasi terhadap proses pembelajaran dan mengamati RPP yang disusun guru. Segala kejadian yang terkait dengan proses pembelajaran dicatat. Pada siklus 1 guru telah diberikan penilaian untuk Mengetahui tingkat pencapaian Kompetensi Pedagogik guru

\section{Refleksi}

Dari hasil observasi pelaksanaan tindakan pada siklus I, maka dilakukan refleksi sebagai acuan penyusunan rencana tindakan pada siklus II sebagai berikut:

a. Mensosialisasikan kembali penerapan supervisi akademik pada guru sehingga guru lebih memahami apa yang harus dilakukan selama pembelajaran berlangsung

b. Membimbing guru dalam menyusun rencana pelaksanaan pembelajaran (RPP)

c. Siswa diharapakan tidak segan - segan untuk menyampaikan hal - hal yang belum dimengerti, sehingga materi bisa tuntas di pelajari.

\section{Siklus II}

\section{Perencanaan Tindakan}

Berdasarkan hasil refleksi siklus I, maka disusun rencana tindakan sebagai berikut:

a. Menyusun rencana pelaksanaan pembelajaran yang telah di konsultasikan dengan kepala sekolah

b. Menentukan jadwal supervisi kelas

c. Memberikan pembinaan pada guru yang belum berhasil

d. Menyusun instrumen penilaian pelaksanaan pembelajaran

\section{Pelaksanaan Tindakan}

Secara umum langkah - langkah pelaksanaan tindakan pada siklus II sama dengan langkah - langkah pelaksanaan tindakan pada siklus I, hanya saja membahasan guru yang belum berhasil dalam menyusun RPP dan masih kurang dalam proses pembelajaran, kemudian pada pertemuan kedua dilaksanakan supervisi kelas berkelanjutan untuk mengetahui peningkatan kompetensi pedagogik guru.

\section{Observasi}

Selama pelaksanaan tindakan Siklus II dilakukan observasi terhadap proses pembelajaran bagi guru yang dikategorikan belum berhasil

\section{Refleksi}

Selanjutnya pada tahap refleksi peneliti menetapkan skor yang diperoleh masing masing guru, kemudian dikerjakan dan direngking untuk mengetahui tingkat pencapaian kompetensi pedagogik guru setelah tindakan. 


\section{Teknik Analisis Data}

Berdasarkan data yang dikumpulkan dalam penelitian ini, baik pada siklus I maupun siklus II, sesuai prosedur rencangan penelitian yang telah di tetapkan maka peneliti berkeyakinan bahwa hasil kesimpulan nantinya akan dapat disampaikan telah melalui analisis. Pada penelitian ini teknik analisis data yang digunakan adalah Analisis Deskriptif - Kuantitatif dengan demikian kesimpulannya nantinya dapat di publikasikan secara bertanggung jawab.
Data Kompetensi Pedagogik guru didapatkan dari supervisi kelas masing masing guru dengan mengunakan instrumen penilaian pelaksanaan pembelajaran pada saat proses pembelajaran

\section{Data RPP Guru}

Data RPP guru diambil dari masing masing guru kemudian dikumpulkan unuk selanjutnya diamati dengan menggunakan instrumen penilaian rencana pembelajaran, berdasarkan aspek - aspek yang ada pada penyusunan RPP.

\section{Data Kompetensi Pedagogik Guru}

\section{Analisis Data}

Tabel 1.Kreteria penggolongan pelaksana pembelajaran guru

\begin{tabular}{cll}
\hline No & \multicolumn{1}{c}{ Interval } & \multicolumn{1}{c}{ Kategori } \\
\hline 1 & $\mathrm{X} \geq \mathrm{MI}+1,5$ SDI & Sangat baik \\
\hline 2 & $\mathrm{MI}+0,5 \mathrm{SDI} \leq \mathrm{X}<\mathrm{MI}+1,5$ SDI & Baik \\
\hline 3 & $\mathrm{MI}+0,5 \mathrm{SDI} \leq \mathrm{X}<\mathrm{MI}+0,5$ SDI & Cukup \\
\hline 4 & $\mathrm{MI}-0,5$ SDI $\leq \mathrm{X}<\mathrm{MI}-0,5$ SDI & Kurang \\
\hline 5 & $\mathrm{X}<\mathrm{MI}-1,5$ SDI & Sangat kurang \\
\hline ( Narkencanadan Sunartana, 1986 )
\end{tabular}

Sedangkan Mean Ideal ( MI ) dan Standar Deviasi Ideal ( SDI ) dihitung dengan menggunakan rumus:

MI $=1 / 2($ Skor tertinggi ideal + Skor terendah ideal )

$$
\mathrm{SDI}=\frac{1}{6}(\text { Skor tertinggi ideal }-
$$

Skor terendah ideal )

Penilaian yang digunakan memiliki skor tertinggi 100 dan skor terendah ideal 0 , dengan demikian dapat ditentukan MI dan SDI sebagai berikut:

$$
\begin{aligned}
\text { MI } & =\frac{1}{2}(100+0) \\
& =50 \\
\text { SDI } & =\frac{1}{6}(100+0) \\
& =16.67
\end{aligned}
$$

\begin{tabular}{|c|c|c|}
\hline No & Interval & Kategori \\
\hline 1 & $X \geq 75$ & Sangat baik \\
\hline 2 & $58,34 \leq X<75$ & Baik \\
\hline 3 & $41,67 \leq X<58,34$ & Cukup \\
\hline 4 & $25 \leq X<41,67$ & Kurang \\
\hline 5 & $X<25$ & Sangat kurang \\
\hline
\end{tabular}

Sehingga kreteria penggolongan kompetensi pedagogik guru menjadi seperti tabel berikut:

Tabel 2.Kreteria penggolongan Kompetensi Pedagogik Guru

Selanjutnya pada tahap menetapkan jumlah skor yang diperoleh masing - masing guru dalam menyusun Rencana

Pelaksanaan Pembelajaran (RPP), 
kemudian direkap dan selanjutnya di rengking. Kemudian ditetapkan keberhasilan guru dalam menyusun RPP sebagai berikut:

a. Jika Skor yang diperoleh guru lebih besar dan sama dengan 15 (skor $\geq 15$ ) guru tersebut dinyatakan telah berhasil menyusun RPP

b. Jika skor yang diperoleh guru lebih kecil dari 15 (skor < 15) dinyatakan guru belum berhasil menyusun RPP ( Gagal )

c. Guru yang belum berhasil menyusun RPP (Gagal) tersebut selanjutnya diprogram untuk mengikuti siklus selanjutnya.

\section{PEMBAHASAN}

Penelitian tindakan sekolah yang telah dilaksanakan ini terbagi kedalam dua siklus, dan melibatkan 1 orang guru SD Negeri9 DauhPurisebagai objek penelitian.

\section{Hasil Penelitian Siklus I}

Data Kompetensi Pedagogik Guru, ditunjukan dari skor penelitian pelaksanaan pembelajaran masing masing guru pada tiap - tiap akhir siklus. Distribusi tingkat Kompetensi Pedagogik Guru pada siklus I disajikan pada tabel berikut:

Tabel 3. Tingkat Kompetensi Pedagogik Guru pada Siklus I

\begin{tabular}{ccccc}
\hline No & Rentang Skor & Kategori & Banyak Guru & Presentase \\
\hline 1 & $75-100$ & Sangat Baik & 0 & $66,67 \%$ \\
\hline 2 & $58,34-74$ & Baik & 0 & $0 \%$ \\
\hline 3 & $41,67-58,34$ & Cukup & 1 & $33,33 \%$ \\
\hline 4 & $25-41,67$ & Kurang & 0 & $0 \%$ \\
\hline 5 & $0-25$ & Sangat Kurang & 0 & $0 \%$ \\
\hline
\end{tabular}

Dari hasil diatas dapat kita lihat bahwa dari SD Negeri9 DauhPuriterdapat 1 orang guru Kompetensi Pedagogiknya termasuk kategori kurang.Pada tahap ini peneliti memeriksa RPP buatan guru dan memasukan skornya kedalam instrumen yang telah disiapkan, kemudian dihimpun seperti pada tabel berikut:

Tabel 4. Tingkat Kemampuan Guru dalam Menyusun RPP

\begin{tabular}{cccc}
\hline Rentang Skor & Jumlah Guru & Prosentase & Keterangan \\
\hline $25-28$ & 0 & $33,33 \%$ & Berhasil \\
\hline $20-24$ & 0 & $16,67 \%$ & Berhasil \\
\hline $15-19$ & 0 & $16.67 \%$ & Berhasil \\
\hline $10-14$ & 1 & $33,33 \%$ & Gagal \\
\hline $5-9$ & 0 & $0 \%$ & Gagal \\
\hline $0-4$ & 0 & $0 \%$ & Gagal \\
\hline Jumlah & 3 & $100 \%$ & \\
\hline
\end{tabular}

Dari hasil diatas dapat dilihat bahwa di SD Negeri9 DauhPuri terdapat 1 orang guru tidak sesuai dengan kreteria penilaian termasuk tidak memiliki RPP.

\section{Hasil Penilaian Siklus II}

1. Perencanaan

Pada tahap ini peneliti merencanakan memanggil guru - guru yang belum berhasil atau tuntas pada Kompetensi Pedagogik maupun menyusun RPP 
2. Pelaksanaan

Pada tahap ini peneliti memeriksa RPP buatan guru dan melakukan supervisi kelas, serta memasukan skornya kedalam instrumen yang dipersiapkan

3. Hasil Pengamatan

Dari pengamatan peneliti diperoleh cerminan seperti tabel berikut:

Tabel 5. Tingkat Kompetensi Pedagogik Guru pada Siklus II

\begin{tabular}{cccc}
\hline Rentang Skor & Kategori & Banyak Guru & Prosentase \\
\hline $75-100$ & Sangat Baik & 1 & $50 \%$ \\
\hline $58,34-74$ & Baik & 0 & $50 \%$ \\
\hline $41,67-58,34$ & Cukup & 0 & $0 \%$ \\
\hline $25-41,67$ & Kurang & 0 & $0 \%$ \\
\hline $0-25$ & Sangat Kurang & 0 & $0 \%$ \\
\hline
\end{tabular}

Dari Siklus II menunjukan bahwa terdapat 1 orang guru (100\%) berhasil meningkatkan Komptensi Pedagogik setelah diberikan pembinaan langsung terhadap hal - hal yang sifat khusus, yang perlu perbaikan dengan segera pada siklus II. Secara kuantitatif dan kualitatif setelah kedua siklus dilaksanakan maka 1 orang guru SD Negeri9 DauhPuriberhasil (100\%) meningkat $33.33 \%$.

Tabel 6. Tingkat Kemampuan Guru dalam Menyusun RPP

\begin{tabular}{cccc}
\hline Rentang Skor & Jumlah Guru & Prosentase & Keterangan \\
\hline $25-28$ & 1 & $66,67 \%$ & Berhasil \\
\hline $20-24$ & - & $33,33 \%$ & Berhasil \\
\hline $15-19$ & - & $0 \%$ & - \\
\hline $10-14$ & - & $0 \%$ & - \\
\hline $5-9$ & - & $0 \%$ & - \\
\hline $0-4$ & - & $0 \%$ & - \\
\hline Jumlah & 1 & $100 \%$ & - \\
\hline
\end{tabular}

Pada tabel diatas menunjukan bahwa 1 orang guru telah berhasil menyusun RPP setelah diberikan pembinaan langsung terhadap hal - hal yang sifat khusus, yang perlu perbaikan dengan segera pada siklus II. Sehingga secara kuantitatif dan kualitatif setelah kedua siklus dilaksanakan maka 1 orang guruKelas IVSD Negeri9 DauhPuriBerhasil (100\%) menyusun RPP dengan peningkatan $50 \%$.

\section{PENUTUP}

\section{Kesimpulan}

Berdasarkan hasil analisis data dan pembahasan hasil penelitian dapat disampaikan sebagai berikut:

a. Penerapan Supervisi Akademik dalam proses pembelajaran dapat meningkatkan Kompetensi Pedagogik GuruKelas IVSD Negeri9 DauhPuri.

b. Penerapan Supervisi Akademik dapat meningkatkan Kompetensi Guru Kelas IV SD Negeri9 DauhPuridalam menyusun RPP. 


\section{Saran}

Adapun hal yang dapat disarankan terkait dengan penelitian ini adalah sebagai berikut:

a. Diharapkan dalam pelaksanaan pembelajaran hendaknya guru mengikuti pedoman yang telah ditetapkan RPP sesuai ketentuan pada Permen 41 Tahun 2007 Tentang Standar Proses

b. Kepala sekolah hendaknya menggunakan kewenangannya dalam pembinaan guru sesuai Tipoksinya.

c. Pengawas Sekolah dalam melaksanakan Supervisi hendaknya menetapkan penerapan Supervisi Akademik dalam pengamatan proses kegiatan pembelajaran.

\section{DAFTAR PUSTAKA}

Dodd, W.A. 1972. Primary School Inspection in New Countries. London: Oxford University Press.
Glickman, C.D., Gordon, S.P., and RossGordon, J.M. 2007. Supervision and Instructional Leadership A Development Approach. Seventh Edition. Boston: Perason.

Gwynn, J.M. 1961. Theory and Practice of Supervision. New York: Dodd, Mead \& Company.

Robbins, S.P.2008. The Truth about Managing People. Second Edition. Upper Sadle River, New Jersey: Pearson Education, Inc.

Sergiovanni, T.J. 1982. Supervision of Teaching. Alexandria: Association for Supervision and Curriculum Development.

Sullivan, S. \&Glanz, J. 2005. Supervision that Improving Teaching Strategies and Techniques. Thousand Oaks, California: Corwin Press.

Verma, V.K. 1996. The Human Aspects of Project Management Human Resources Skills for the Project Manager. Volume Two. Harper Darby,PA: Project Management Institute. 